\title{
FIRST NOTE ON MARINE-LIKE CEMENTATION OF LATE HOLOCENE BEACHROCK, IZNIK LAKE (TURKEY)
}

\author{
AHMET E. ERGINAL ${ }^{1}$, NAFIYE G. KIYAK ${ }^{2}$, MUHAMMED Z. OZTURK ${ }^{1}$, ERDINC YIGITBAS $^{3}$, \\ MUSTAFA BOZCU ${ }^{3}$, MUSTAFA AVCIOGLU ${ }^{3}$ and BEYHAN OZTURK ${ }^{1}$ \\ ${ }^{I}$ Department of Geography, Canakkale Onsekiz Mart University, TR-17100, Canakkale, Turkey \\ ${ }^{2}$ Department of Physics, Işık University, TR-34980, Şile, Istanbul, Turkey \\ ${ }^{3}$ Department of Geology Engineering, Canakkale Onsekiz Mart University, TR-17020 Canakkale, Turkey
}

Received 4 January 2011

Accepted 9 September 2011

\begin{abstract}
Micro-fabric characteristics and optically stimulated luminescence (OSL) dating results are presented to discuss the controlling agents and timing of beachrock cementation on the fresh-water Iznik Lake shoreline. The beachrocks are made up of grain-supported polygenic conglomerate containing $20.42 \%$ carbonate with encrusted grains, basically as micrite coatings, isopachous aragonite rims, cryptocrystalline void fills and meniscus bridges. The optical ages of twelve samples yielded ages that range from $4.226 \pm 0.569 \mathrm{ka}$ on the lowermost beds to $0.706 \pm 0.081$ on the uppermost. This is the first report of precipitation of marine-like cements in Iznik Lake. The abundant aragonitedominated cement is likely indicative of precipitation-prone dry evaporative conditions from the climatic optimum to the last millennia.
\end{abstract}

Keywords: Beachrock cementation, Carbonate precipitation, Late Holocene, Iznik Lake, Turkey.

\section{INTRODUCTION}

In the present study, we discuss the nature and age of beachrock that formed in a fresh-water lake environment in northwest Turkey. In the strict use of the term, beachrock is known to occur mostly along tropical and subtropical coasts as well as the Mediterranean (Ginsburg 1953; Bricker, 1971) and its carbonate cement is of prime significance in interpreting the real place of cementation. Precipitation from mixed marine and meteoric waters, groundwaters, sea waters and marine microorganisms have often been accepted as governing factors of the source of the connective carbonate (see ref. in Vousdoukas et al., 2007). The precipitation directly from freshwater lakes is, however, restricted to a few examples

Corresponding author: A. E. Erginal

e-mail: aerginal@comu.edu.tr
(Jones et al., 1997; Binkley et al., 1980) which both differ in terms of the nature of their cement (i.e. silica and low-Mg calcite, respectively) rather than beachrocks rich solely in aragonite, as discussed in this paper. Thus, a drawback arises in interpreting coastal structures such as real beachrock without considering the nature of the cement material.

Our knowledge on the origin and absolute age of beachrocks on Turkey's coastline is limited to a few recent publications (Erginal et al., 2008; Desruelles et al., 2009; Erginal et al., 2010). In this paper, we combine field descriptions and spectroscopic data with optical dating results to highlight the governing factors and timing of carbonate precipitation that have led to tight induration of beachrock grains and gravels under favourable climatic and hydrologic conditions. Kayan (1996) was first to deal with the existence of beachrock on the Iznik 
Lake shoreline and suggested these occurrences formed when the lake was at a lower level.

\section{CLIMATE AND GEOLOGY}

Lying at latitudes $40^{\circ} 30^{\prime}-40^{\circ} 22^{\prime}$ north and longitudes $29^{\circ} 20^{\prime}-29^{\circ} 42^{\prime}$ east, the Iznik Lake (32 km long, $12 \mathrm{~km}$ wide) occupies an east-west trending tectonic depression, a pull-apart basin formed by the middle branch of the right-lateral North Anatolian Fault between Karlık and Gürle-Avdan mountain ranges to the north and south, respectively. The fresh waters of this perennial lake are drained today by the Karsak Stream that flows westward, i.e. into the Marmara Sea, through a deep gorge carved into Paleozoic marbles and Trias metamorphic rocks. To the east of the lake is the so-called Karadin valley, a WSW-ENE trending tectonic corridor slightly inclined to the lake (Fig. 1a, b).
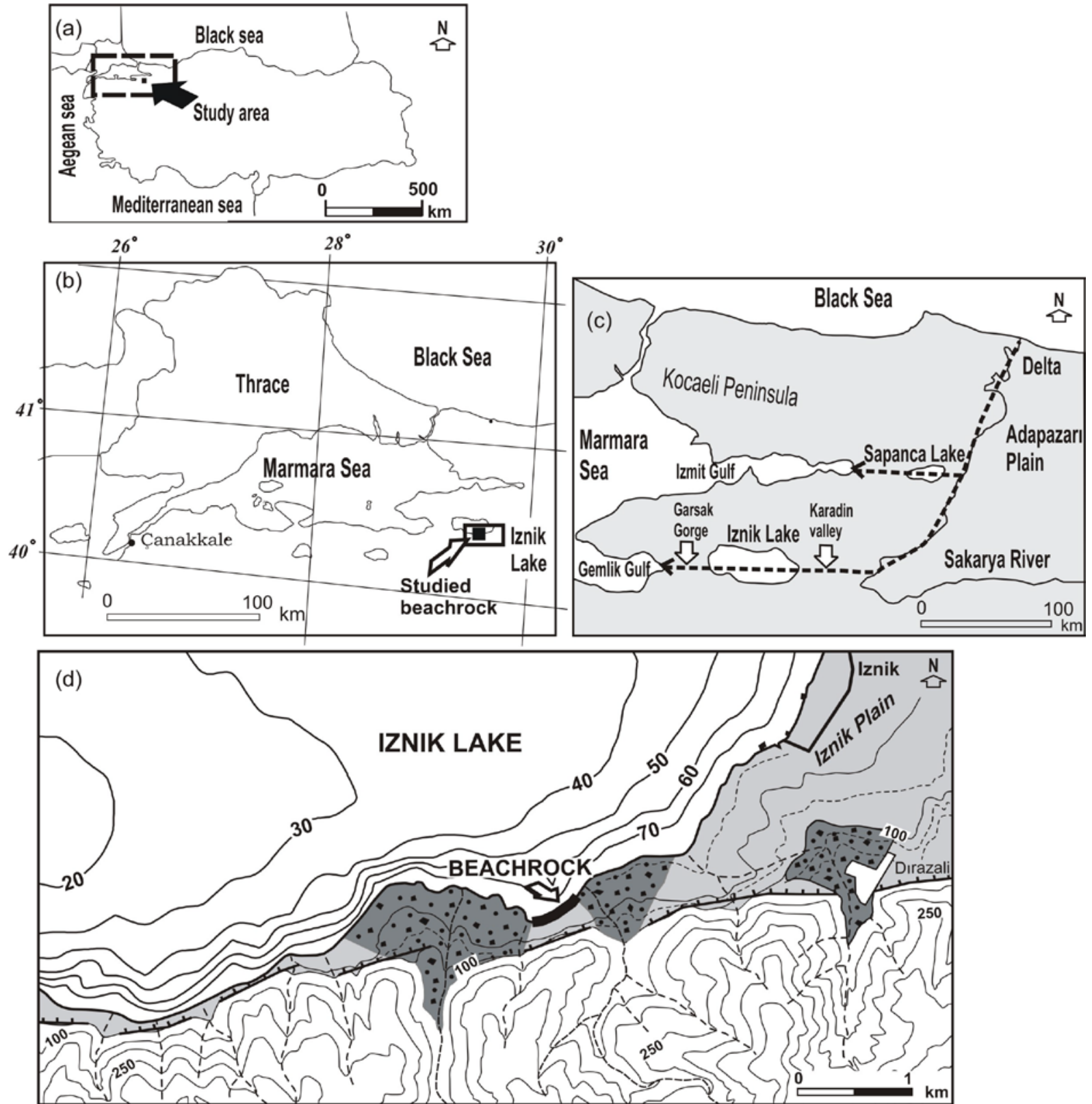

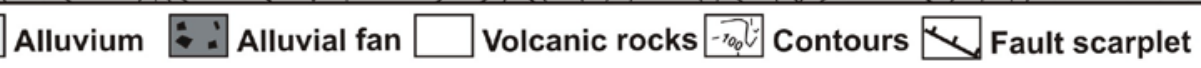

\section{Streams}

Fig. 1. Location ( $a$ and $b$ ), the possible ways for the connection of the lake to the sea during late Pleistocene (c), and simplified morphologic units (d) of study area. 
Having a water level about $85 \mathrm{~m}$ above sea-level, the lake has a drainage area of $1246 \mathrm{~km}^{2}$, total surface area of $313 \mathrm{~km}^{2}$ and a maximum depth of $80 \mathrm{~m}$ (Ozturk et al., 2009). Hydro-chemically, the lake waters are warmmonomictic (Franz et al., 2006). The climate of the lake area is typically Mediterranean, represented by hot-dry summers and cold-rainy winters. The temperatures (annual average $15.1^{\circ} \mathrm{C}$ ) range between $6.7^{\circ} \mathrm{C}$ and $24.6^{\circ} \mathrm{C}$. The average annual precipitation is $737.9 \mathrm{~mm}$. On average, the lake level shows insignificant annual variations of $50 \mathrm{~cm}$ during its low (May to November) and high (December to April) periods.

\section{METHODOLOGY}

\section{Analyses of connective cement}

A total of twelve samples of beachrock were collected for micro-fabric analysis and optical luminescence dating. For interpretation of facies characteristics, scanning electron microscopy (SEM-ZEISS EVO 50 EP) coupled with Energy Dispersive Spectroscopy (EDX-Bruker AXS XFlash) was used due to the advantages of the high magnification limit as well as the three-dimensional imaging and elemental characterization of the connective cement. A Scheibler calcimeter (Schlichting and Blume, 1966) was used to determine the total $\mathrm{CaCO}_{3}$ content. The measurements of $\mathrm{pH}$ were carried out using a WTW multi-parameter device. $U$, Th and $\mathrm{K}$ values within the beachrock cements were derived from Inductively Coupled Atomic Mass Spectroscopy (ICP-MS). The lake water composition was also analyzed using Atomic emission spectrometry (ICP-AES). Mineral constituents within the beachrocks was analysed by means of X-ray diffractometry (XRD).

\section{Sample preparation and equivalent dose $\left(D_{e}\right)$ estimate}

Quartz grains of 90-180 $\mu \mathrm{m}$ in the beachrock deposits were extracted, wet-sieved and treated with $\mathrm{HCl}$ and $\mathrm{H}_{2} \mathrm{O}_{2}$ for the removal of carbonates and organics prior to HF treatment to etch the outer surface of the quartz grains. The parts affected by alpha radiation were removed and then the samples were treated with HCL once more. The grains were subjected to infrared stimulation and no feldspar contamination was detected. The clean quartz grains were then spread on a stainless-steel disc using silicon spray for OSL measurement. The luminescence signals were measured by a Risø TL/OSL reader with blue $(470 \mathrm{~nm})$ light stimulation through U-340 filters (Bøtter-Jensen, 1997). The equivalent dose accumulated in the quartz was calculated by the optically stimulated luminescence single-aliquot regenerative-dose (OSL-SAR) protocol as presented in Table 1 (Murray and Wintle, 2000). All laboratory procedures were performed under subdued red light. Aliquots from each sample were preheated at $260^{\circ} \mathrm{C}$ and then stimulated for $40 \mathrm{~s}$ at $125^{\circ} \mathrm{C}$ to record natural and regenerative OSL signals, respectively $\left(L_{n}, L_{i}\right)$. For testing the sensitivity change between the cycles, a test dose was administered to a cutheat temperature. Test dose OSL signals were then recorded $\left(T_{n}, T_{i}\right)$. The equivalent dose $D_{e}$ was obtained from interpolation of the corrected natural signal $\left(L_{n} / T_{n}\right)$ on the growth curve drawn by the use of sensitivity-corrected dose points $\left(L_{i} / T_{i}\right)$. Fig. 2 presents the growth curve constructed for a representative sample, L2-5.2, where regenerative doses were employed from 0 to $10 \mathrm{~Gy}$.

For reliability in the OSL measurements, a known laboratory dose close to the natural dose was given to the bleached aliquots and evaluated by OSL-SAR protocol. The aliquots were also tested by the repeatability of a regenerative dose on the dose-response curve, recycling ratio, and recuperation, a measure of bleachability of the OSL signal compared to the natural signal. The annual dose rate of the natural environment for each sample was derived from $\mathrm{U}$, Th and $\mathrm{K}$ concentrations obtained by ICP-ES/ICP-MS analysis (Table 2). The $\beta$ and $\gamma$ dose rates were calculated from radioisotope concentrations

Table 1. Single-aliquot regenerative-dose (SAR) protocol for OSL dose evaluation (Murray and Wintle, 2000).

\begin{tabular}{llc}
\hline & Sequence in cycles & Measurement \\
\hline 1 & Natural+ three regenerative doses & - \\
\hline 2 & Preheat $260^{\circ} \mathrm{C}$ for $10 \mathrm{~s}$ & - \\
\hline 3 & OSL signal for $40 \mathrm{~s}$ at $125^{\circ} \mathrm{C}$ & $L_{n}, L_{i}$ \\
\hline 4 & Test dose & - \\
\hline 5 & Cut heat to $190^{\circ} \mathrm{C}$ & - \\
\hline 6 & OSL signal for $40 \mathrm{~s}$ at $125^{\circ} \mathrm{C}$ & $T_{n}, T_{i}$ \\
\hline 7 & Return to 1 & - \\
\hline
\end{tabular}

1) In the first cycle natural signal and following cycles regenerative doses were between 0-10 Gy.

2) $260^{\circ} \mathrm{C}$ defined from preheat plateau test.

4) Test dose administered as 10-20\% of natural dose.

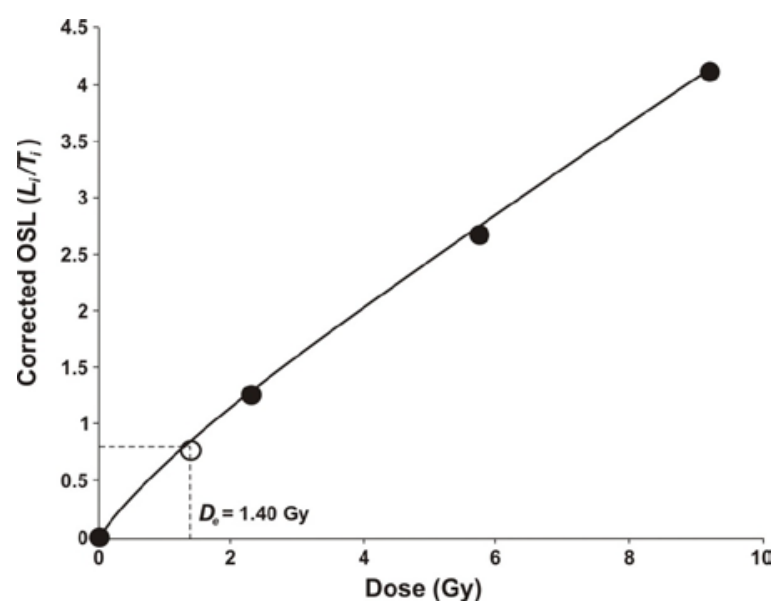

Fig. 2. Growth curve of quartz from representative sample $L 2-5.2$ shows almost linear behaviour for a dose range from 0 to $10 \mathrm{~Gy}$. Equivalent dose $\mathrm{D}_{\mathrm{e}}$ was obtained from interpolation of corrected natural OSL signal. 
using the conversion factors of Adamiec and Aitken (1998). The cosmic ray contribution to the dose rate was calculated using the formula given by Prescott and Hutton (1988). The moisture content and carbonate fraction affecting the dose rate evaluation were also taken into account.

\section{RESULTS AND DISCUSSION}

\section{Stratigraphy and composition of cement}

The beachrock ledges and sampling sites that were chosen from submerged, near-shore and backshore sections are shown in Fig. 3. On the studied lake shoreline, the beachrocks comprise hard indurated $545 \mathrm{~m}$-long slabs that dip towards the lake at distinctive angles varying between $4^{\circ}$ and $15^{\circ}$. The shoreline-parallel ledges are predominantly composed of grain-supported polygenic conglomerate, containing angular or subrounded gravels of marble, serpentine, various volcanics, sandstone and limestone derived from the surrounding highlands. The uppermost surface of the beds is grey to light black in colour due to thin coatings of dead freshwater algae.

Looking at a vertical section of the beds, we see that conglomerate predominates on the top; progressing downwards to a finer grained sandstone. However, beds may exhibit variations in stratigraphic order. A variance in the fabric of clasts can also be recognized, represented by plane-parallel regular bedding to disorganized and poorly imbricated gravels and cobbles. Even though beds are commonly $40 \mathrm{~cm}$-thick due to severe wave erosion, they show an eastward thickening attaining up to $1.6 \mathrm{~m}$ where the cemented beach also reaches $11 \mathrm{~m}$ in width. The western part of the beachrock zone is, however, rather different in that beds of $40 \mathrm{~cm}$-thickness have higher angles of about $25^{\circ}$. Throughout the cemented beach, beds close to the lake are eroded and dislocated, the upper levels of which are marked by notches and grooves. To the south, behind the beach, beds terminate with the Iznik-Orhangazi highway, while the submerged beds may be followed up to 5 meters offshore.

Table 2. Several measured parameters of beachrocks.

\begin{tabular}{cccccccc}
\hline $\begin{array}{c}\text { Lab } \\
\text { Code }\end{array}$ & $\begin{array}{c}\text { Depth } \\
(\mathbf{c m})\end{array}$ & $\begin{array}{c}\text { Cosmic } \\
(\text { Gy/ka) }\end{array}$ & $\begin{array}{c}\text { WC } \\
(\text { sat-\%) }\end{array}$ & $\begin{array}{c}\mathrm{CaCO}_{3} \\
(\%)\end{array}$ & $\begin{array}{c}\mathbf{U} \\
(\mathbf{p p m})\end{array}$ & $\begin{array}{c}\text { Th } \\
(\mathbf{p p m})\end{array}$ & $\begin{array}{c}\mathrm{K} \\
(\%)\end{array}$ \\
\hline 1.1 & 5 & 0.3 & 7.7 & 22.83 & 0.5 & 1 & 0.13 \\
\hline 1.2 & 5 & 0.3 & 7.89 & 20.04 & 0.5 & 1.2 & 0.11 \\
\hline 1.3 & 5 & 0.3 & 7.34 & 28.84 & 0.5 & 0.9 & 0.11 \\
\hline 1.4 & 20 & 0.25 & 5.61 & 20.96 & 0.5 & 1.2 & 0.13 \\
\hline 2.1 & 5 & 0.3 & 8.03 & 24.64 & 0.6 & 1.1 & 0.12 \\
\hline 2.2 & 40 & 0.2 & 9.48 & 22.08 & 0.5 & 1.2 & 0.13 \\
\hline 2.3 & 120 & 0.18 & 8.72 & 20.07 & 0.5 & 1.2 & 0.14 \\
\hline 3.1 & 5 & 0.3 & 8.45 & 22.3 & 0.5 & 1.1 & 0.14 \\
\hline 3.2 & 30 & 0.22 & 12.76 & 12.91 & 0.7 & 1.6 & 0.18 \\
\hline 3.3 & 5 & 0.31 & 6.56 & 14.99 & 0.5 & 1.4 & 0.18 \\
\hline 4.1 & 5 & 0.28 & 6.64 & 21.1 & 0.5 & 1 & 0.13 \\
\hline 4.2 & 30 & 0.21 & 10.29 & 14.3 & 0.6 & 1.7 & 0.2 \\
\hline
\end{tabular}

WC: water content.
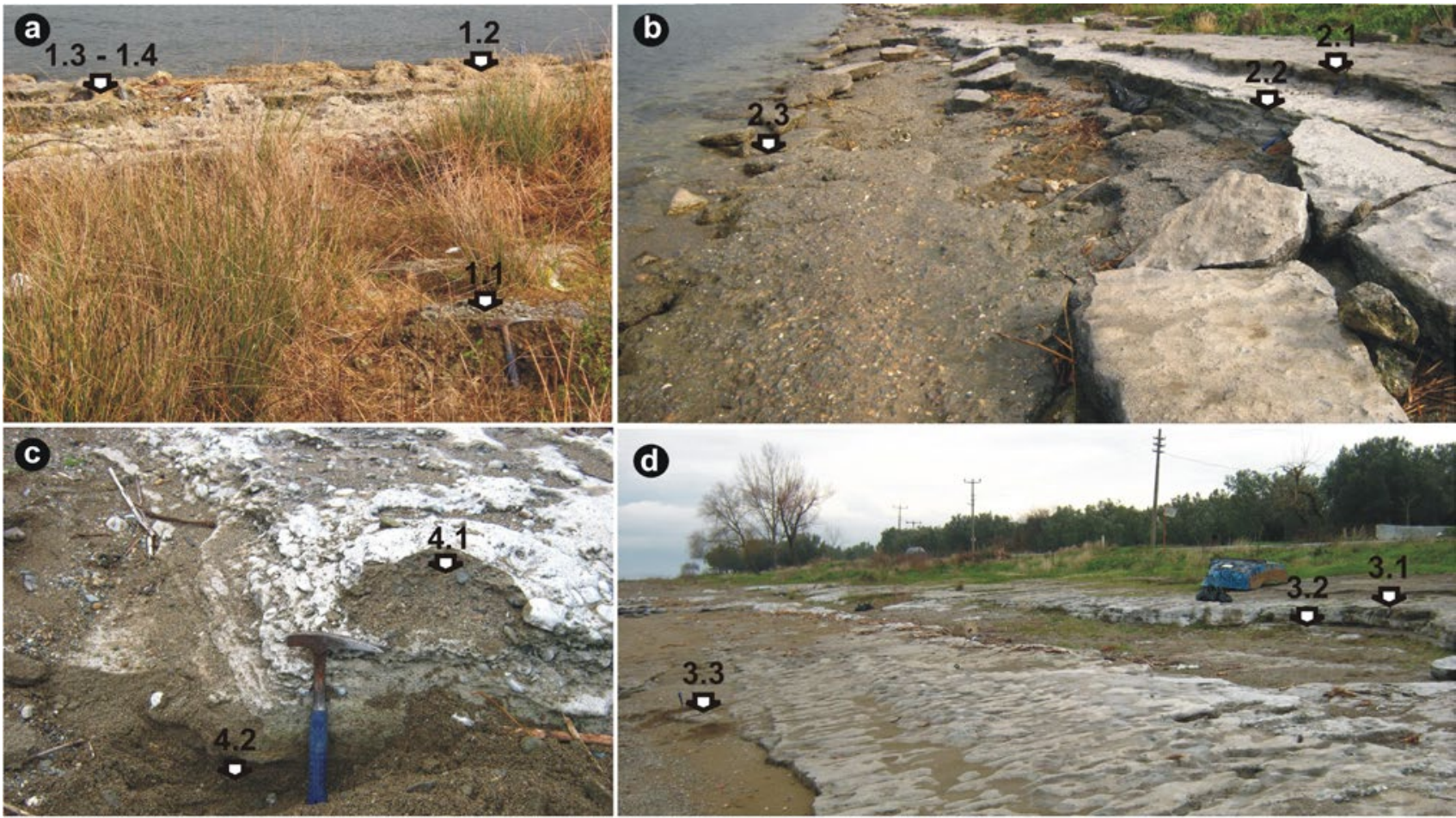

Fig. 3. Views of studied cemented beach. Numbers indicate sample codes. 
Based on the measurement of carbonate content, these beachrocks contain carbonate that ranges between $28.84 \%$ and $12.91 \%$ (average: $20.42 \%$ ). The average EC and $\mathrm{pH}$ values were found to be $99.97 \mu \mathrm{s}$ and $8.8 \mu \mathrm{s}$, respectively. EDX analysis (Table 3) revealed that elemental composition of the cements consisted, in decreasing amounts, of $\mathrm{Ca}>\mathrm{O}>\mathrm{C}>\mathrm{Si}>\mathrm{K}>\mathrm{Al}>\mathrm{Fe}>\mathrm{Mg}>\mathrm{Na}$. Aragonite and calcite are the main elements of the connective carbonate cement and other accessory minerals consist of quartz, rutile and abundant coesite, based on XRD data. The presence of rutile and particularly coesite as a high temperature and high pressure polymorph of $\mathrm{SiO}_{2}$, appears to be somewhat mysterious, as this is mostly found in impact craters and ultra-metamorphic rocks such as eclogites. Because there is no source area for derivation of this unusual quartz in the lake basin, the mineral could have been transported from areas outside the basin as result of drainage input at some time in the past. However, further more-detailed petrographic analyses are needed to confirm its presence.

\section{Cement types}

As is known, proper identification of the cementation area of beachrock depends mainly on characterization of both the chemical nature of the connective cement and the micromorphology or crystal structure of the precipitated carbonaceous compounds. This can be achieved thanks to microanalysis methods such as SEM/EDX and $\mathrm{XRD}$, having been applied convincingly in several previous beachrock studies (Holail and Rashed, 1992; Vollbrecht and Meischner, 1993; Kneale and Viles, 2000). The composition and physical characteristics of beachrock in the studied beach are explained here based upon interpretation of these spectroscopic data. A total of 88 SEM images were taken to define the cement fabrics of the beachrocks. SEM images showed that the precipitated cements are quite similar to those of marine origin, as discussed below.
As evidence of the distinctive places and stages of carbonate precipitation, SEM images show that various types of cement morphologies exist, such as thick micrite coatings, isopachous aragonite rims, cryptocrystalline void fills and meniscus bridges. In almost all samples, micrite coatings preponderate, suggestive of an initial stage of precipitation of carbonate cements in consequence of supersaturation of pore waters (Vieira and De Ros, 2006). These encrustations that developed on poorly rounded or angular silica-clastic grains ranging in size between $500 \mu \mathrm{m}$ and $1 \mathrm{~mm}$ have a thickness of up to $50 \mu \mathrm{m}$ (Fig. 4a, b). Closer viewing of those overgrowths shows the existence of successive encrustations rather than one single layer. The lower layers, as early precipitates, are comprised entirely of equigranular aragonite needles (Fig. 4c), which cause a considerable decrease in porosity. These micrite-sized $(\leq 4 \mu \mathrm{m})$ crystals have blade-edged scalenohedral terminations and constitute reciprocal clumps on the aragonite rims. The overlying aragonites are also scalenohedral-shaped but larger in size (up to $10 \mu \mathrm{m}$ ), protruding as second generation precipitates from the micrite coatings.

Micritic pore-filling cement is another type of cement, which co-exists with thin meniscus bridges (Fig. 4d), in particular, on the surface and age of angular grains. Thick plasters of carbonate are typical of precipitation from carbonate-saturated waters and are likely the result of closure of pores due to lateral widening in the meniscus bridges. These inter-granular bridges have thicknesses that vary between $20 \mu \mathrm{m}$ and $50 \mu \mathrm{m}$. Several previous studies have been made on the precipitation of meniscus cement from carbonate-rich meteoric waters (Friedman, 1964; Scoffin and Studdart 1983; Spurgeon et al., 2003; Rey et al., 2004). However, the bridges in this study are composed solely of micritic aragonite crystals, which could therefore also be related to precipitation around organic filaments by trapping of percolating micrite (Hillgärtner et al., 2001).

Table 3. EDX results obtained from beachrock cements.

\begin{tabular}{ccccccccccc}
\hline Sample & Analysis surface & $\mathbf{C}$ & $\mathbf{0}$ & $\mathbf{N a}$ & $\mathbf{M g}$ & $\mathbf{A l}$ & $\mathbf{S i}$ & $\mathbf{K}$ & $\mathbf{C a}$ & $\mathbf{F e}$ \\
\hline 1.1 & Mikrite coating & 2.96 & 7.15 & 0.13 & 1.09 & 0.89 & 1.80 & 0.68 & 84.25 & 1.05 \\
\hline 1.2 & Mikrite coating & 3.14 & 9.02 & 1.20 & 1.52 & 1.21 & 2.49 & 4.41 & 76.92 & 1.09 \\
\hline 1.3 & Radial Aggregate & 2.10 & 4.44 & 0.18 & 0.46 & 0.55 & 1.03 & - & 90.57 & 0.67 \\
\hline 1.4 & Mikrite coating & 4.38 & 8.61 & 0.23 & 0.36 & 0.23 & 0.36 & 0.60 & 83.59 & 1.65 \\
\hline 2.1 & Mikrite coating & 3.10 & 7.46 & 0.35 & 0.63 & 0.50 & 0.66 & 0.28 & 85.49 & 1.53 \\
\hline 2.2 & Mikrite coating & 4.97 & 11.19 & 0.36 & 1.42 & 0.51 & 0.65 & 4.29 & 75.15 & 1.47 \\
\hline 2.3 & Mikrite coating & 2.56 & 5.89 & - & 0.86 & 1.68 & 7.27 & 4.89 & 76.85 & - \\
\hline 3.1 & Mikrite coating & 4.44 & 17.23 & 0.39 & 1.61 & 4.31 & 7.70 & 5.29 & 59.26 & 2.77 \\
\hline 3.2 & Mikrite coating & 20.98 & 43.10 & 0.89 & 1.55 & 0.68 & 0.74 & 0.37 & 30.83 & 0.85 \\
\hline 3.3 & Mikrite coating & 17.17 & 38.56 & 0.71 & 4.02 & 2.32 & 3.54 & 0.85 & 29.45 & 3.38 \\
\hline 4.1 & Mikrite coating & 15.71 & 40.62 & 1.29 & 5.33 & 6.72 & 12.91 & 1.89 & 12.38 & 3.16 \\
\hline 4.2 & Mikrite coating & 16.89 & 40.27 & 0.71 & 4.02 & 6.61 & 11.36 & 2.03 & 13.65 & 4.45 \\
\hline & Average & 14.24 & 17.01 & 0.49 & 1.72 & 2.02 & 3.77 & 2.49 & 56.46 & 1.95 \\
\hline
\end{tabular}


The third kind of cement is made up of isopachous aragonite rims, consisting of randomly-orientated aragonites, which range from $10 \mu \mathrm{m}$ to $50 \mu \mathrm{m}$ in length (Fig. 4e, f). The intergranular pores are densely filled by those reciprocal crystals that protrude from the surfaces and edges of the angular grains. As is known, such prismatic
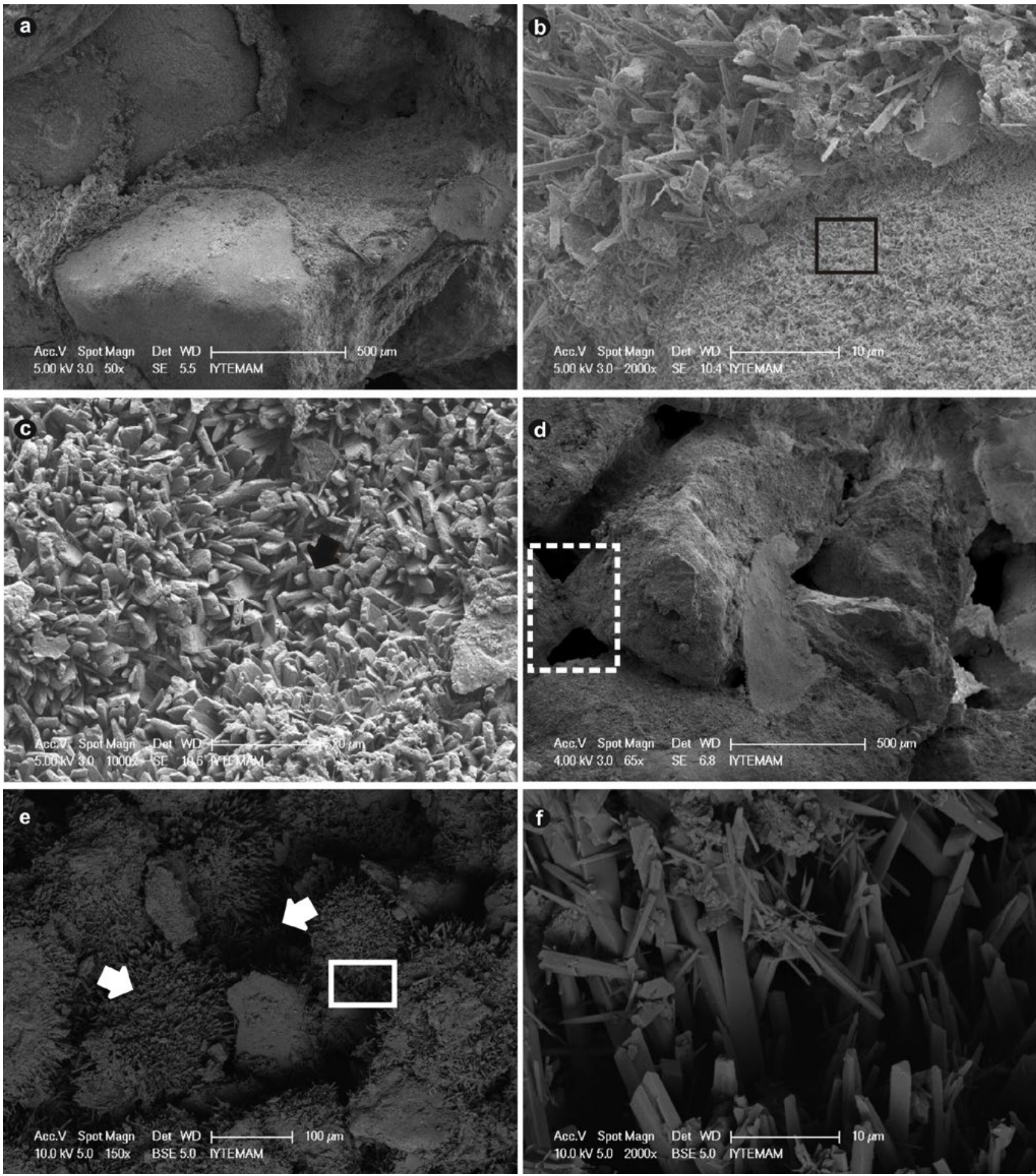

Fig. 4. SEM images showing (a-b) micrite precipitates on grain surfaces and boundaries as thin encrustations and (c) closer view of same thin films (square) dominated by patchy aragonite needles (black arrow); (d) typical meniscus bridge (dashed rectangular) co-existing with pore fills; (e) isopachous aragonite rims and (f) closer view of those rims (white rectangular). 
crystal rims are regarded to be indicative of shallow marine phreatic conditions (Vieira and De Ros, 2006), together with micrite films and pore infills.

\section{Holocene lake-level variations based on optical ages}

Unlike many studies which pointed to increased water levels during the Pleistocene era (Ardel 1953; Tanoglu and Erinc, 1956) or sea-water connections (Islamoglu, 2009; Nazik et al., 2010), there are very limited field data that suggest Holocene water-level variations in Iznik Lake.

In this study, twelve samples of beachrock extracted from different levels and sites were dated using optical dating. The luminescence age, equivalent dose and environmental dose rate obtained for each sample are presented in Table 4. The uncertainty in OSL age of the aliquots from each sample was found to be about $10 \%$. The ages reveal that the first accumulation of beachrock grains and gravels occurred $4.23 \pm 0.57 \mathrm{ka}$ ago when the lowermost layers at $1.2 \mathrm{~m}$ depth were accumulated. The ages of near-surface samples extracted from a depth of $5 \mathrm{~cm}$, however, yielded ages ranging between 0.70 and $1.35 \mathrm{ka}$.

These age values suggest that the cementation history of the beachrocks encompasses a time period of $3.5 \mathrm{ka}$. The different ages determined for distinct levels from $5 \mathrm{~cm}$ to $1.2 \mathrm{~m}$ is worth considering, because it might be suggestive of episodically developed induration of the beds. Induration of such a thick beach material could have occurred via precipitation of carbonate cement due to increased evaporation conditions, possibly when the level of the lake was decreasing, which is supported by previous geo-archeological and geomorphological data. Kayan (1996) also proposed, based on geo-archaeological data from the late Neolithic Ilipinar settlement west of the lake, that a lake level a few meters higher was followed by drier and hotter climatic conditions during the climatic optimum between $6 \mathrm{ka}$ and $3 \mathrm{ka}$, which, as he suggested, favoured formation of beachrocks at lower water levels. The transition in climate in the Mediterranean during the

Table 4. OSL-SAR dose estimates and OSL age values of samples.

\begin{tabular}{lccccc}
\hline $\begin{array}{l}\text { Lab. } \\
\text { code }\end{array}$ & $\begin{array}{c}\text { Depth } \\
(\mathbf{c m})\end{array}$ & OSL Age (ka) & Paleodose (Gy) & (n) & $\begin{array}{c}\text { Dose rate } \\
\text { (Gy/ka) }\end{array}$ \\
\hline 1.1 & 5 & $0.954 \pm 0.097$ & $1.15 \pm 0.11$ & 13 & $1.206 \pm 0.029$ \\
\hline 1.2 & 5 & $0.908 \pm 0.091$ & $1.11 \pm 0.11$ & 12 & $1.218 \pm 0.035$ \\
\hline 1.3 & 5 & $0.706 \pm 0.081$ & $0.807 \pm 0.090$ & 14 & $1.144 \pm 0.033$ \\
\hline 1.4 & 20 & $1.04 \pm 0.20$ & $0.53 \pm 0.10$ & 12 & $0.506 \pm 0.034$ \\
\hline 2.1 & 5 & $0.820 \pm 0.062$ & $0.985 \pm 0.069$ & 12 & $1.201 \pm 0.034$ \\
\hline 2.2 & 40 & $2.17 \pm 0.40$ & $0.95 \pm 0.16$ & 14 & $0.439 \pm 0.032$ \\
\hline 2.3 & 120 & $4.23 \pm 0.57$ & $1.84 \pm 0.21$ & 12 & $0.436 \pm 0.033$ \\
\hline 3.1 & 5 & $0.946 \pm 0.060$ & $1.142 \pm 0.065$ & 13 & $1.2072 \pm 0.0031$ \\
\hline 3.2 & 30 & $3.12 \pm 0.39$ & $1.78 \pm 0.19$ & 9 & $0.570 \pm 0.034$ \\
\hline 3.3 & 5 & $1.350 \pm 0.099$ & $1.82 \pm 0.12$ & 8 & $1.349 \pm 0.049$ \\
\hline 4.1 & 5 & $1.000 \pm 0.084$ & $1.201 \pm 0.090$ & 12 & $1.201 \pm 0.046$ \\
\hline 4.2 & 30 & $2.16 \pm 0.58$ & $1.22 \pm 0.31$ & 10 & $0.567 \pm 0.046$ \\
\hline
\end{tabular}

"Number of aliquots evaluated.
mid-Holocene has been criticized recently by Roberts et al. (2011a), pointing out an oscillatory decline in winter precipitations after $\sim 6 \mathrm{ka} \mathrm{BP}$. This transition was comprised of three stages; each eventuated in drier periods from 5.3 to $2.8 \mathrm{ka} \mathrm{BP}$ (Roberts et al., 2011b). The intense droughts occurred, for instance, in central Anatolia at the end of $6^{\text {th }}, 5^{\text {th }}$ and $4^{\text {th }}$ millennia BP, based on sedimentological data from sediments of Tecer lake (Kuzucuoglu et al., 2011).

Regression in level of the lake waters is also supported by morphological data by Ikeda et al. (1991), who paid attention to a sequence of subparallel beach ridges on the western shore marked by dune crests 1-2 m higher than the present lake level. They suggested, given the lack of absolute ages, that these ridges formed during short-lived stillstands of a regressional stage which followed the last high stand of the lake.

As explained above, marine-like cement micro-fabrics within the beachrocks might have implications concerning the source or, at least, the chemical composition of the water from which the connective aragonite cements were precipitated. Our data indicate that a decline in lake level favouring carbonate precipitation during drier periods could be suggested because sections of the beachrock ledges are submerged today. However, Late Pleistocene was possibly characterized by higher water levels than Late Holocene. On the north shore of the lake, the first author recently detected a fossiliferous beachrock that contains abundant Cerastoderma glaucum shells (unpublished data). Based on the fact that this fossil shell is typical of salt marine-waters, the finding confirms a suggestion that the lake was connected with the sea at $39790 \pm 360$ BP based on AMS radiocarbon age (Beta, USA) from fossil shell of C. glaucum. However, Nazik et al., 2010 suggested a Holocene connection based on the presence of ostracode Limnocythere inopinata sevanensis Bubikyan, which is typical of brackish Black Sea waters (Nazik et al., 2010). These new findings have the potential to explain the initial precipitation of marine-like cements in present-day Iznik Lake. However, precise assessment of the origin or controlling agents of the precipitation of the aragonite cement depends on more comprehensive analysis of carbonate chemistry and stable isotope determinations, which will be discussed in a subsequent paper.

\section{CONCLUSIONS}

The cementation characteristics and optical age of Late Holocene beachrock on the southeast shoreline of Iznik Lake were examined in this study. Petrographically, the cemented beach materials comprise a grain-supported polygenic conglomerate, consisting of poorly rounded gravels of marble, serpentine, various volcanics, sandstone and limestone. The defined marine-like cements, such as micritic coatings, isopachous rims, cryptocrystalline void fills and meniscus bridges, are all composed of 
aragonite and have features similar to those formed in a marine phreatic zone. Suggesting only slightly changed levels in the lake, optical luminescence ages revealed that the beachrock cementation occurred at Late Holocene and that favourable conditions existed in historical times.

\section{ACKNOWLEDGEMENTS}

We are grateful to the Scientific and Technological Research Council of Turkey (TUBITAK, Project number: 109Y143) who financially supported the project.

\section{REFERENCES}

Adamiec G and Aitken MJ, 1998. Dose-rate conversion factors: update. Ancient TL 16: 37-50.

Ardel A, 1953. İznik Depresyonu ve Gölü (The Iznik Depression and Lake). İstanbul Universitesi Coğrafya Enstitusu Dergisi 2: 210225 (in Turkish).

Binkley KL, Wilkinson BH and Owen RM, 1980. Vadose beachrock cementation along a southeastern Michigan marl lake. Journal of Sedimentary Petrology 50: 953-962, DOI 10.1306/212F7B302B24-11D7-8648000102C1865D.

Bøtter-Jensen L, 1997. Luminescence techniques: instrumentation and methods. Radiation Measurements 17: 749-768, DOI 10.1016/S1350-4487(97)00206-0.

Bricker OP, 1971. Introduction: beachrock and intertidal cement. In: Bricker OP, ed., Carbonate Cements. John Hopkins Press, Baltimore M.D: 1-3.

Desruelles S, Fouache E, Çiner A, Dalongeville R, Pavlopoulos K, Koşun E, Coquinot Y and Potdevin JL, 2009. Beachrocks and sea level changes since Mid-Holocene: comparison between the insular group of Mykonos-Delos-Rhenia (Cyclades, Greece) and southern coast of Turkey. Global and Planetary Change Letters 66: 19-33, DOI 10.1016/j.gloplacha.2008.07.009.

Erginal AE, Kiyak NG, Bozcu M, Ertek TA, Gungunes H, Sungur A and Turker G, 2008. On the origin and age of the Ariburnu beachrock, Gelibolu Peninsula, Turkey. Turkish Journal of Earth Sciences 17: 803-819.

Erginal AE, Kiyak NG and Ozturk B, 2010. Investigation of beachrock using microanalyses and OSL dating: A case study from Bozcaada Island, Turkey. Journal of Coastal Research 26(2): 350-358, DOI 10.2112/08-1151.1.

Franz SO, Schwark L, Bruchmann C, Scharf B, Klingel R, Van Alstine JD, Çağatay $\mathrm{N}$ and Ulgen UB, 2006. Results from a Multidisciplinary Sedimentary Pilot Study of Tectonic Lake Iznik (NW Turkey)-Geochemistry and Paleolimnology of the Recent Past. Journal of Paleolimnology 35: 715-736, DOI 10.1007/s10933005-5015-3.

Friedman GM, 1964. Early diagenesis and lithification in carbonate sediments. Journal of Sedimentary Petrology 34: 777-813, DOI 10.1306/74D71195-2B21-11D7-8648000102C1865D.

Ginsburg RN, 1953. Beachrock in South Florida. Journal of Sedimentary Petrology 23: 85-92, DOI 10.1306/D4269558-2B26-11D78648000102C1865D.

Hillgärtner H, Dupraz C and Hug W, 2001. Microbially induced cementation of carbonate sands: are micritic meniscus cements good indicators of vadose diagenesis? Sedimentology 48(1): 117131, DOI 10.1046/j.1365-3091.2001.00356.x.

Holail H and Rashed M, 1992. Stable isotopic composition of carbonate-cemented recent beachrock along the Mediterranean and Red Sea coasts of Egypt. Marine Geology 106: 141-148, DOI 10.1016/0025-3227(92)90059-Q.

Ikeda Y, Herece E, Svgai T and Işıkara A.M, 1991. Post glacial crustal deformation associated with slip on the Western part of the North Anatolian Fault Zone in the Iznik Lake Basin, Turkey. Bulletin of the Department of Geography University of Tokyo 23: 13-23.
Islamoglu Y, 2009. Middle Pleistocene bivalves of the Iznik lake basin (Eastern Marmara, NW Turkey) and a new paleobiogeographical approach. International Journal of Earth Sciences (Geologische Rundschau) 98: 1981-1990, DOI 10.1007/s00531-008-0344-x.

Jones B, Rosen MR and Renaut RW, 1997. Silica-cemented beachrock from Lake Taupo, north island, New Zealand. Journal of Sedimentary Research 67: 805-814, DOI 10.1306/D42686442B26-11D7-8648000102C1865D.

Kayan İ, 1996. İznik Gölü batısındaki Ilıpınar Höyüğü çevresinde jeomorfolojik ve jeo-arkeolojik araştırmalar, Ege Coğrafya Dergisi 9: 43-70 (in Turkish).

Kneale D and Viles HA, 2000. Beach cement: incipient $\mathrm{CaCO}_{3}-$ cemented beachrock development in the upper intertidal zone, North Uist, Scotland. Sedimentary Geology 132: 165-170, DOI 10.1016/S0037-0738(00)00029-4.

Kuzucuoğlu C, Dörfler W and Kunesch S, 2011. Mid- to late-Holocene climate change in central Turkey: The Tecer Lake record. The Holocene 21(1): 173-188, DOI 10.1177/0959683610386819.

Murray AS and Wintle AG, 2000. Luminescence dating of quartz using an improved single-aliquot regenerative-dose protocol. Radiation Measurements 32: 57-73, DOI 10.1016/S1350-4487(99)00253-X.

Nazik A, Meriç E, Avşar N, Ünlü S, Esenli V and Gökaşan E, 2010. Possible waterways between the Marmara Sea and the Black Sea in the late Quaternary: evidence from ostracod and foraminifer assemblages in lakes Iznik and Sapanca, Turkey. Geo-Marine Letters 31: 75-86, DOI 10.1007/s00367-010-0216-9.

Ozturk K, Yaltirak C and Alpar B, 2009. The relationship between the tectonic setting of the Lake Iznik basin and the middle strand of the North Anatolian Fault. Turkish Journal of Earth Sciences 18: 209-224, DOI 10.3906/yer-0803-4.

Prescott JR and Hutton JT, 1988. Cosmic ray and gamma ray dosimetry for TL and ESR. Nuclear Tracks Radiation Measurements 14: 223-227, DOI 10.1016/1359-0189(88)90069-6.

Rey D, Rubio B, Bernabeu AM and Vilas F, 2004. Formation, exposure, and evolution of a high-latitude beachrock in the intertidal zone of the Corrubedo complex (Ria de Arousa, Galicia, NW Spain). Sedimentary Geology 169: 93-105, DOI 10.1016/j.sedgeo.2004.05.001.

Roberts N, Brayshaw D, Kuzucuoglu C, Perez R and Sadori L, 2011a. The mid-Holocene climatictransition in the Mediterranean:Causes and consequences. The Holocene 21(1): 3-13, DOI $10.1177 / 0959683610388058$.

Roberts N, Eastwood WJ, Kuzucuoglu C, Fiorentino G and Caracuta V, 2011b. Climatic, vegetation and cultural change in the eastern Mediterranean during the mid-Holocene environmental transition. The Holocene 21(1): 147-162, DOI 10.1177/0959683610386819.

Schlichting E and Blume E, 1966. Bodenkundliches practicum. Verlag paul Parey, Hamburg un Berlin.

Scoffin TP and Stoddart DR, 1983. Beachrock and intertidal cement. In: Goudie AS and Pye K, eds, Chemical Sediments and Geomorphology: precipitates and residua in the near-surface environment. Academic Press, London: 401-425.

Spurgeon D, Davis Jr, R.A and Shinnu EA, 2003. Formation of 'Beach Rock' at Siesta Key, Florida and its influence on barrier island development. Marine Geology 200: 19-29, DOI 10.1016/S00253227(03)00162-2.

Tanoğlu A and Erinc S, 1956. Garsak boğazı ve Eski Sakarya (The Garsak gorge and the Sakarya River diversion). İstanbul Universitesi Coğrafya Enstitusu Dergisi 4: 17-31 (in Turkish).

Vieira MM and De Ros LF, 2006. Cementation patterns and genetic implications of Holocene beachrocks from northeastern Brazil. Sedimentary Geology 192(3-4): 207-230, DOI 10.1016/j.sedgeo.2006.04.011.

Vousdoukas MI, Velegrakis AF and Plomaritis TA, 2007. Beachrock occurrence, characteristics, formation mechanism and impacts. Earth-Science Reviews $\quad 85: \quad 23-46, \quad$ DOI 10.1016/j.earscirev.2007.07.002.

Vollbrecht R and Meischner D, 1993. Sea-level and diagenesis - a casestudy on Pleistocene beaches, Whalebone Bay, Bermuda. Geologische Rundschau 82(2): 248-262, DOI 10.1007/BF00191831. 